\title{
The Principle of Ambituity and the Prohibition against Excessive Collateral Damage to the Environment during Armed Conflict
}

\author{
Erik V. Koppe* \\ Assistant Professor of Public International Law, Faculty of Law and the Grotius Center for \\ International Legal Studies, Leiden University, Leiden, The Netherlands
}

\begin{abstract}
This article aims to clarify the legal basis of the protection of the environment during armed conflict in general, and of the prohibition against excessive collateral damage to the environment in particular. It is submitted that the legal basis for the conventional and customary rules which protect the (intrinsic value of the) environment during armed conflict cannot be deduced from the four fundamental principles of the law of armed conflict: the principles of military necessity, distinction, proportionality and humanity. Rather, the specific obligations relating to environmental protection in times of armed conflict flow from the fundamental principle of ambituity. Similar to the principle of humanity, the principle of ambituity, which qualifies as a general principle of law in the sense of Article 38(1)(c) ICJ Statute, provides for an absolute limitation to the necessities of war. As such the principle of ambituity may be used to interpret existing conventional or customary rules of international law during armed conflict, to supplement, or under exceptional circumstances to modify or set aside these rules. With regard to the prohibition against excessive collateral damage to the environment during armed conflict, it is submitted that this prohibition flows from a customary rule which emerged in the 1990s, rather than from Articles $5^{1}$ and $5^{2}$ of Additional Protocol I, and which complements Articles 35 and 55 AP I (i.e. for States Parties to AP I). This article argues that any military action which causes collateral damage to the environment must first be assessed under this relatively new customary prohibition; and subsequently, if no breach can be established and if applicable, by reference to Articles 35(3) and 55 AP I. In order to enhance the scope of this prohibition and provide better protection for the environment against collateral damage it is suggested that further investigations should be conducted into the consequences of warfare on the environment.
\end{abstract}

Keywords

general principles; Article 38(1)(c) ICJ Statute; environment; armed conflict; collateral damage; ambituity

*) The author wishes to thank Dr. Heinsch, Dr. Molier and Ms. Dam, LL.M., for their comments. 


\section{Introduction}

In recent years, relatively little attention has been paid to protection of the environment during armed conflict. Indeed, and for obvious reasons, the primary focus of attention during armed conflict has not been on the protection of flora and fauna, but rather on the protection of the victims of armed conflict. However, the consequences of warfare on the environment cannot be underestimated. The consequences of the use of anti-plant agents such as Agent Orange during the Vietnam war between 1961 and $1971,{ }^{1}$ the burning of oil wells and the leaking of oil into the Persian Gulf during the 1990-1991 Gulf War and the oil spill in the Mediterranean Sea following an attack on a power plant in Lebanon during the 2006 Israel-Lebanon war were devastating, not only for flora and fauna, but also for civilians. Indeed, it was these devastating consequences which triggered the debate on the need for (further) international regulation of the means and methods of warfare. The use of Agent Orange partly triggered the drafting of Articles 35(3) and 55 of Additional Protocol I (AP I) in 1977, which prohibit the use of means and methods of warfare which are intended or expected to cause widespread, long-term and severe damage to the environment. ${ }^{2}$ More recently, this author has argued that the burning oil wells and oil spills in the Persian Gulf in $1991,{ }^{3}$ triggered the emergence of three relatively new rules of customary international law relating to the protection of the environment during armed conflict: a prohibition of wanton destruction of the environment during armed conflict; a prohibition against excessive collateral damage to the environment during armed conflict; and the obligation to observe a general duty of care for the environment during armed conflict. ${ }^{4}$ It is notable that the International Committee of the Red Cross (ICRC) came to a similar conclusion in its Customary International Humanitarian Law Study (CIHL Study) of 2005 (Rules 43 and 44).5

1) On the legality of the United States' use of chemicals during the Vietnam war, see W. D. Verwey, 'Chemical Warfare in Vietnam: Legal or Illegal?', 18 Netherlands International Law Review (1971); W. D. Verwey, Riot Control Agents and Herbicides in War; Their Humanitarian, Toxicological, Ecological, Military, Polemological, and Legal Aspects (A.W. Sijthoff, Leiden, 1977). 2) See for example the explanatory statement of Hungary relating to its proposal to include an environmental protection provision in Additional Protocol I. CDDH/III/64, 19 March 1974 (III, 221), proposed additional paragraph, by Czechoslovakia, German Democratic Republic, Hungary, in: H. Levie, Protection of War Victims: Protocol 1 to the 1949 Geneva Conventions; Volume 3 (Oceana Publications, Dobbs Ferry, NY, 1980) p. 259.

3) These events also triggered a call for the drafting of a fifth Geneva Convention, which would be specific for the protection of the environment during armed conflict. G. Plant (ed.), Environmental Protection and the Law of War; A 'Fifth Geneva' Convention on the Protection of the Environment in Time of Armed Conflict (Belhaven Press, London, 1992).

4) For a discussion of emergence of such custom and the evidence on which this conclusion is based, see E. Koppe, The Use of Nuclear Weapons and the Protection of the Environment during International Armed Conflict (Hart Publishing, Oxford, 2008) pp. 246-278.

5) J.-M. Henckaerts and L. Doswald-Beck (eds.), Customary International Humanitarian Law; Volume I and II, International Committee of the Red Cross (Cambridge University Press, Cambridge, 2005) (also through $<$ www.icrc.org $>$ ). 
Although the need to protect the environment is generally recognised by States, ${ }^{6}$ the key challenge is to observe and, if necessary, enforce these rules of ius in bello. ${ }^{7}$ One way to ensure compliance with existing rules is to clarify their meaning and scope. To that end, in 2011 the International Law Commission (ILC) decided to include the "protection of the environment in relation to armed conflicts" in its long-term programme of work. ${ }^{8}$ The ILC was of the opinion that discussing this topic would make a useful contribution to the codification and progressive development of international law while it would also allow the ILC to venture into fields of international law which it has hitherto not considered, such as international humanitarian law and international environmental law.

In light of the possible future work by the ILC on this topic, this article seeks to clarify the legal basis of the protection of the environment during armed conflict in general, and of the prohibition against excessive collateral damage to the environment in particular. Section 2 discusses the mutual relationship between the specific conventional and customary rules relating to the protection of the environment during armed conflict and the general or fundamental principles of the law of armed conflict. Section 3 discusses the legal basis for and scope of the prohibition against excessive collateral damage to the environment during armed conflict. The article concludes with a brief summary, conclusion and suggestions for consideration by the ILC (Section 4).

\section{The Principle of Ambituity}

\subsection{Introduction}

In order to understand the current legal framework in relation to the protection of the environment during armed conflict, it is pertinent to provide clarity as to its foundations. This section will first discuss the principles of the law of armed conflict in general (section 2.2) and in relation to the protection of the environment during armed conflict in particular (section 2.3). Subsequently, the

6) See the 1972 Stockholm Declaration (principle 26), the 1982 World Charter for Nature (para. 5), the 1992 Rio Declaration (principle 24), and the 2002 Johannesburg Final Declaration (para. 19). See also A/Res/47/37, adopted without a vote on 25 November 1992, on the protection of the environment in times of armed conflict; and A/Res/56/4, adopted without a vote on 5 November 2001; Observance of the International Day for Preventing the Exploitation of the Environment in War and Armed Conflict.

7) Please note that protection of the environment during armed conflict also follows from the ius ad bellum and the ius pacis. See Koppe, supra note 4, pp. 309-333 (ius ad bellum) and pp. 335-364 (ius pacis). On the relationship and overlap between ius ad bellum and ius in bello, see also E. Koppe, 'Compensation for War Damages under Jus ad Bellum', in A. de Guttry et al. (eds.), The 1998-200o War between Eritrea and Ethiopia; An International Legal Perspective (T.M.C. Asser Press, The Hague, 2009).

8) A/66/10, Report of the International Law Commission; Sixty-third session (26 April-3 June and 4 July -12 August 2011), para. 365 . 
relationship of the principles of the law of armed conflict to general principles of law will be discussed (section 2.4) followed by consideration of the consequences of the recognition of the principles of the law of armed conflict as general principles of law (section 2.5).

\subsection{The Principles of the Law of Armed Conflict}

It is generally agreed that the law of armed conflict is founded on four fundamental principles: the principle of military necessity; the principle of distinction; the principle of proportionality; and the principle of humanity. ${ }^{9}$ The object and purpose of the law of armed conflict, and of these four principles in particular, is "alleviating as much as possible the calamities of war" as befitting civilised nations. ${ }^{10}$

Pursuant to the principle of military necessity States are allowed to use military force - in deviation of the law of peace ${ }^{11}$ - in order to weaken the military forces of the enemy. ${ }^{12}$ The inherent limitation of this objective of warfare is further

9) One may also add the general principle of chivalry (or the treachery or perfidy principle according to Greenwood) and the precautionary principle. The former prohibits the use of dishonorable means or methods of warfare, recognised in the United States Navy Manual on the Law of Naval Warfare of 1959. The latter is reflected in Articles 57 and $5^{8}$ AP I and entails an obligation for belligerent states to take constant care to spare civilians and civilian objects during hostilities. As such the precautionary principle is a sub-principle of the principle of necessity and closely linked with the principles of distinction and proportionality. See R. Kolb and R. Hyde, An Introduction to the International Law of Armed Conflicts (Hart Publishing, Oxford, 2008) p. 44. C. Greenwood, 'The law of war (international humanitarian law)', in M.D. Evans (ed.), International Law, 1st edition (Oxford University Press, 2003) p. 802.

10) St. Petersburg Declaration Renouncing the Use, in Time of War, of Explosive Projectiles Under 400 Grammes Weight, signed on 11 December 1868, entered into force on 11 December 1868, 1 American Journal of International Law; Supplement: Official Documents (1907) p. 95, preambular paras. $1-2$.

11) A/CN.4//SER.A/1980/Add.1 (Part 2), Yearbook of the International Law Commission, 1980, Vol. II, Part Two, Report of the Commission to the General Assembly on the work of its thirtysecond session, pp. $45^{-46 .}$

12) St. Petersburg Declaration Renouncing the Use, in Time of War, of Explosive Projectiles Under 400 Grammes Weight, signed on 11 December 1868, entered into force on 11 December 1868, 1 American Journal of International Law, Supplement: Official Documents (1907) p. 95, preambular para. 3. This object and purpose is repeated in Article 3 of the 1880 Oxford Manual on the Law of War on Land, adopted by the Institut de Droit International (which was established in 1873). Through <www.icrc.org $>$. Cf. also the descriptions of military necessity in the 1863 Lieber Code, in which military necessity was understood as consisting of measures "which are indispensable for securing the ends of the war" (Article 14) admitting "all direct destruction of life or limb or armed enemies, and of other persons whose destruction is incidentally unavoidable in the armed contests of the war" (Article 15). Through <www.icrc.org $>$. The US Military Tribunal in Nuremberg ruled in the Hostages Trial: "Military necessity permits a belligerent ... to apply any amount and kind of force to compel the complete submission of the enemy ..." United States Military Tribunal (Nuremberg), Case No. 47; The Hostages Trial; Trial of Wilhelm List and Others; 8th July, 1947-19th February, 1948, in The United Nations War Crimes Commission, Law Reports of Trials of War Criminals; Volume VIII (His Majesty's Stationary Office, London, 1949) p. 66 . 
reflected in the (sub-) principles of distinction and proportionality. ${ }^{13}$ If the only legitimate object of warfare is to weaken the military forces of the enemy, it is axiomatic that States must distinguish between combatants and civilians and between military objects and civilian objects (distinction) and that they must keep any unintentional or collateral damage to civilians and civilian objects to a minimum (proportionality). This right to use military force, ${ }^{14}$ as reflected in the principle of military necessity, is generally limited by the principle of humanity, ${ }^{15}$ which provides an absolute limitation on particular means and methods of warfare during armed conflict.

Together these principles form a general and systematic legal framework and a frame of reference for the law of armed conflict. Most rules of the law of armed conflict, both conventional and customary, are reflections of these principles, give expression to these principles, ${ }^{16}$ or are the result of a compromise between these principles, in particular the principles of necessity and humanity. ${ }^{17}$ Indeed, according to Kolb and Hyde,

all rules of the [law of armed conflict] exist at an equilibrium point between two fundamental principles, each of which pulls in a different direction. The contents of the norms of the [law of armed conflict] are the result of particular compromises between these two

13) Oeter identifies two sub-principles following from the general principle of "limited warfare" (limited to what is militarily absolutely necessary in order to achieve the military objectives), one of which is the principle of distinction. S. Oeter, 'Methods and Means of Combat', in D. Fleck et al. (eds.), The Handbook of International Humanitarian Law, 2nd edition (Oxford University Press, Oxford, 2008) para. 401, no. 2-3. According to the International Court of Justice in the Nuclear Weapons Opinion, however, the principle of distinction qualifies as one of the main principles of international humanitarian law. Legality of the Threat or Use of Nuclear Weapons, 8 July 1996, ICJ, Advisory Opinion, I.C.J Reports 1996, para. 78.

14) According to Greenwood, many "supposed 'belligerent rights' are not rights in the true legal sense at all", since they often do not have correlative duties. "What the law actually confers in such a case is a liberty; the person (or state) concerned may exercise that liberty without violating the law but others are under no duty to cooperate with him or even to abstain from obstructing him. ... The notion that the ius in bello leaves states and individuals free to act in a particular way without giving them a "right" to do so is one aspect of a fundamental principle of that law. That principle is that war (or armed conflict) is not an institution established by international law but a fact which the law has always recognized and attempted to contain. ... Thus, each side in a conflict might lawfully kill the other's soldiers in open combat, not because international law gave it a right to kill but because international law left it alone to kill or not according to its ability and inclination." C. Greenwood, "The Relationship between ius ad bellum and ius in bello', 9 Review of International Studies (1983) pp. 228-229.

15) St. Petersburg Declaration Renouncing the Use, in Time of War, of Explosive Projectiles under 400 Grammes Weight, preambular paras. 1, 5-6.

16) Military and Paramilitary Activities in and against Nicaragua (Nicaragua v. United States of America), 27 June 1986, ICJ, I.C.J. Reports 1986, paras. 218 and 220. See also Oeter, supra note 13, para. 401, no. 1

17) Y. Sandoz et al. (eds.), Commentary on the Additional Protocols; of 8 June 1977 to the Geneva Conventions of 12 August 1949 (International Committee of the Red Cross, Martinus Nijhoff Publishers, Geneva, 1987), para. 1389. The Commentary is also available through $<w w w$ .icrc.org>. 
fundamental principles made during the negotiation of treaties, or decisions made by states to adopt particular practices. The two fundamental principles are the principle of humanity on the one hand and the principle of military necessity on the other."18

A general reflection of this compromise between the principle of military necessity and the principle of humanity is laid down in Article 35(1) of Additional Protocol I, ${ }^{19}$ which provides that "the right of the Parties to the conflict to choose methods or means of warfare is not unlimited". 20 The principle of humanity is particularly reflected in Article 35(2) AP I which contains a general prohibition on "[the employment of] weapons, projectiles and materials and methods of warfare of a nature to cause superfluous injury or unnecessary suffering"; ${ }^{21}$ and it has found expression in specific prohibitions on the use of particular conventional $^{22}$ and non-conventional weapons. ${ }^{23}$ The principles of distinction and

18) Kolb and Hyde, supra note 9, p. 43. Similarly M. Schmitt, 'Military Necessity and Humanity in International Humanitarian Law: Preserving the Delicate Balance', 50 Virginia Journal of International Law (2009-2010) p. 798; G. Schwarzenberger, International Law; As Applied by International Courts and Tribunals; Volume II; The Law of Armed Conflict (Stevens \& Sons, London, 1968) pp. 10-13.

19) Protocol Additional to the Geneva Conventions of 12 August 1949, and Relating to the Protection of Victims of International Armed Conflicts, opened for signature on 12 December 1977, entered into force on 7 December 1978, 1125 UNTS, No. 17512.

20) According to Venturini, Article 35(1) AP I mostly clearly articulates the "restraining effect" of the principle of military necessity, which "imposes a restrictive standard on the exercise of warfare: a belligerent must refrain from employing any kind or degree of violence which is not actually necessary for military purposes" and thus to achieve the goals of warfare. G. Venturini, 'Necessity in the Law of Armed Conflict and in International Criminal Law', in I. F. Dekker and E. Hey (eds.), 41 Netherlands Yearbook of International Law (2010) pp. 48-49.

21) According to the International Court of Justice, however, the prohibition against unnecessary suffering qualifies as a separate principle of international humanitarian law. Nuclear Weapons Opinion, supra note 13, para. 78.

22) These prohibitions include the St. Petersburg Declaration Renouncing the Use, in Time of War, of Explosive Projectiles Under 400 Grammes Weight (the use of explosive projectiles under 400 grams would "uselessly aggravate the sufferings of disabled men, or render their death inevitable", and which use therefore was considered to be contrary to "the laws of humanity" (see preambular paras. 4 and 5)). Hague Declaration (IV, 3) on the Use of Bullets Which Expand or Flatten Easily in the Human Body, signed on 29 July 1899, entered into force 4 September 190o, D. Schindler and J. Toman (eds.), The Laws of Armed Conflicts; A Collection of Conventions, Resolutions and Other Documents (Martinus Nijhoff Publishers, Dordrecht, 1988) p. 109. In the Declaration's preamble, the contracting parties stated that this prohibition was "inspired by the sentiments which found expression in the Declaration of St. Petersburg". A further example is the Convention on Prohibitions or Restrictions on the Use of Certain Conventional Weapons Which May be Deemed To Be Excessively Injurious or To Have Indiscriminate Effects and Protocols, opened for signature on 10 April 1981, entered into force on 2 December 1983, 1342 UNTS, No. 22495.

23) Geneva Protocol for the Prohibition of the use in War of Asphyxiating, Poisonous or Other Gases, and of Bacteriological Methods of Warfare, signed 17 June 1925, entered into force on 8 February 1928, 25 American Journal of International Law; Supplement: Official Documents (1931) p. 94; Convention on the Prohibition of the Development, Production, Stockpiling and Use of Chemical Weapons and on Their Destruction, together with Annexes, opened for signature on 13 January 1993, entered into force on 29 April 1997, 1975 UNTS, No. 33757. 
proportionality are currently reflected in Articles 48 and 51(5)(b) AP I as well as in their customary equivalents as identified by the ICRC in its Customary International Humanitarian Law Study. ${ }^{24}$ These rules oblige belligerents to direct their operations against military objectives only and prohibit attacks which may be expected to cause incidental loss of civilians, damage to civilian objects, or a combination thereof, which would be excessive in relation to the concrete and direct military advantage anticipated.

The relationship between these rules and the principle of necessity (which underlies the law of armed conflict) is further evidenced by the references to military necessity as a possible ground for exception from a prohibition. For example, Article $23(\mathrm{~g})$ of the Hague Regulations ${ }^{25}$ prohibits the destruction or seizure of enemy property "unless such destruction or seizure be imperatively demanded by the necessities of war". And Articles 54 and 56 AP I allow derogation on the basis of military necessity and under specific circumstances from the prohibitions on the destruction of objects which are indispensable for the survival of the civilian population and on attacking certain objects which contain dangerous forces.

\subsection{The Principles of the Law of Armed Conflict and the Protection of the Environment during Armed Conflict}

It is difficult, however, to link the above-mentioned rules relating to the protection of the environment during armed conflict to either of these fundamental principles of the law of armed conflict. In particular the general prohibition of Article 35(3) AP I cannot be deduced from the principles of necessity, distinction, proportionality or humanity, nor can it be deduced from a compromise between either of these principles. Article 35 AP I provides:

Article 35 - Basic rules

1. In any armed conflict, the right of the Parties to the conflict to choose methods or means of warfare is not unlimited.

2. It is prohibited to employ weapons, projectiles and material and methods of warfare of a nature to cause superfluous injury or unnecessary suffering.

3. It is prohibited to employ methods or means of warfare which are intended, or may be expected, to cause widespread, long-term and severe damage to the natural environment.

Article 35(3) AP I qualifies as a basic rule of the law of armed conflict and provides for an absolute limitation to the necessities of war in order to protect the intrinsic value of the natural environment, irrespective of its context and relationship with man. The protection of the environment under Article 35(3) is not linked to the

24) Henckaerts and Doswald-Beck, supra note 5 , Rules 1-24, in particular Rule 1 and 14.

25) Hague Convention (IV) Respecting the Laws and Customs of War on Land, with annexed Regulations, signed on 18 October 1907, entered into force on 26 January 1910, 2 American Journal of International Law; Supplement: Official Documents (1908) p. 90. 
distinction between military and civilian objects (like its twin, Article 55 AP I), thereby excluding the principle of distinction and proportionality. The protection of the environment under Article 35(3) is not inspired by nor focused on the protection of human beings or mankind (like Article 35(2) AP I), thereby excluding the principle of humanity. Moreover - as just observed - it provides for an absolute limitation to the necessities of war (as foreseen in Article 35(1) AP I), thereby excluding the principle of military necessity as such.

Thus, in order to explain the emergence of Article 35(3) as well as the customary duty of care for the environment during armed conflict, ${ }^{26}$ a fifth fundamental principle of the law of armed conflict must be identified. ${ }^{27}$ This principle, already recognised by Röling, ${ }^{28}$ reflects the common understanding of States that the environment must be protected during armed conflict, ${ }^{29}$ and provides for an absolute limitation to the necessities of war. As such, this principle is very similar to the principle of humanity, which provides for an absolute limitation to the necessities of war in the interest of man and civilisation.

The existence of this fifth principle as a fundamental principle of the law of armed conflict not only explains the drafting of the specific rules on the protection of the environment in Additional Protocol I, in particular Article 35(3) AP I and the first sentence of Article 55(1) AP I, but it also accounts for the development of the customary rules relating to the protection of the environment during armed conflict which, as noted above, arguably emerged in the 1990s. ${ }^{30}$

For consistency purposes (the principles of necessity, distinction, proportionality and humanity all have a Latin stem), it is suggested to name this principle the

26) Koppe, supra note 4, pp. 248-256. Similarly Rule 44 of the CIHL Study, which provides in part: "Methods and means of warfare must be employed with due regard to the protection and preservation of the natural environment."

27) See Koppe, supra note 4, pp. 117-118.

28) According to Verwey, Röling "submitted proposals aimed at restating traditional, but still workable, principles as well as formulating new ones ... The following new basic principles of modern ius in bello ought to be recognized: ... (c) the principle of the protection of the environment (implying a prohibition on weapons and techniques with a destructive effect on the natural balance, or which introduce destructive and irrevocable ecological processes." W. D. Verwey, 'Bert V.A. Röling (1906-1985)', in T.M.C. Asser Instituut, The Moulding of International Law: Ten Dutch Proponents (T.M.C. Asser Instituut, The Hague, 1995) p. 45.

29) See supra note 6.

30) At a recent conference organised by the Grotius Center for International Legal Studies of Leiden University launching the Grotius Center's Jus Post Bellum Project, Payne argued the existence of a similar norm - the norm of environmental integrity. According to Payne, worldwide efforts to restore natural resources, ecosystems and other elements of the environment in post-conflict interventions imply the existence of a norm of environmental integrity. C. R. Payne, Just Post Bellum and the Norm of Environmental Integrity, conference paper, on file with the author. See also <juspostbellum.com $>$. The role of environmental protection in ius post bellum situations was recently confirmed when the United States and Vietnam started cleaning up Agent Orange on part of Danang International Airport in central Vietnam, where it was stored during the Vietnam War. The US provided USD 41 million for this clean-up operation. News report through $<$ www.reuters.com $>$ (8 and 9 August 2012). 
principle of ambituity, from the Latin word ambitus, which means, among other things, environment. ${ }^{31}$

\subsection{The Principles of the Law of Armed Conflict and the General Principles of Law}

The relevance of the identification of the principle of ambituity is twofold. First, it completes the general framework of the law of armed conflict and positions the conventional and customary rules in relation to the protection of the environment during armed conflict within this framework. Second, it is submitted that the principle of ambituity qualifies as a general principle of the law of armed conflict (or as one of the 'general principles of humanitarian law' as they were qualified by the International Court of Justice (ICJ) in the Nicaragua Judgment $)^{32}$ and therefore as a general principle of law within the meaning of Article 38(1)(c) of the Statute of the ICJ (Statute). As such, it would qualify as an autonomous (and primary) source of international law.

Traditionally "the general principles of law recognized by civilized nations" were understood as referring to general principles of law in foro domestico, i.e. principles of domestic law that are common to all legal systems, such as the principle of good faith and the principle of res iudicata. ${ }^{33}$ There is increasing recognition, however, that Article 38(1)(c) Statute also includes general principles of international law. ${ }^{34}$ This is confirmed, among others, by Mosler ${ }^{35}$ and Gaja ${ }^{36}$ and

31) With special thanks to the present author's former teacher in classic Greek and Latin, Mr. Kluiver and his colleague Mr. Ossewijer.

32) Nicaragua v. United States of America, supra note 16, paras. 218, 220 and 255.

33) A. Pellet, 'Article 38', in A. Zimmermann et al., The Statute of the International Court of Justice; A Commentary (Oxford University Press, Oxford, 2006) pp. 766-773.

34) As a matter of fact Tunkin argued that Article 38(1)(c) Statute ICJ only referred to general principles of international law. In 1945, the drafters of the Statute of the ICJ amended the chapeau of Article 38 of the Statute of the Permanent Court of International Justice (PCIJ) by including the phrase "whose function is to decide in accordance with international law such disputes as are submitted to it". This amendment made Tunkin come to the conclusion that the scope of Article 38(1)(c) would as from 1945 be limited to general principles of international law. G. I. Tunkin, 'General Principles of Law in International Law', in R. Marcic (eds.), Internationale Festschrift für Alfred Verdross: zum 8o. Geburtstag (Fink, München, 1971) p. 525 .

35) Mosler identified general principles of international legal relations as one category of general principles covered by Article $38(1)$ (c) Statute ICJ. These were "principles resulting from the sovereign equality of States (jurisdiction, immunities, self-determination), principles connected with treaties, elementary considerations of humanity, and 'generally accepted principles' related to the law of the seas, diplomatic protection and armed conflict". H. Mosler, 'General Principles of Law', in R. Bernhardt (ed.), Encyclopaedia of Public International Law; Volume Two; East African Community to Italy-United States Air Transport Arbitration (1965) (North-Holland Publishing Company, Amsterdam, 1995) pp. 513-514, 522-524.

36) According to Judge Gaja, the ICJ often refers to principles of international law or general principles which have no parallel in domestic law. The identification of such principles by the ICJ "whether or not it finds a parallel in municipal systems, is only rarely accompanied by an 
recently by Judge Cançado Trindade. ${ }^{37}$ It is submitted that such recognition reflects the emancipation of public international law from a rudimentary legal order consisting mostly of bilateral contractual relationships to a developing legal order on the basis of an increasing number of multilateral (sometimes even universal) legal relationships reflecting common and even global values. ${ }^{38}$

If general principles of international law are recognised as an autonomous source of public international law under Article 38(1)(c) Statute, it is arguable that general principles of certain areas of public international law also fall under the scope of Article 38(1)(c) Statute. Indeed, according to Judge Cançado Trindade, "[t]here are, in fact, general principles of law proper to international law in general, and there are principles of Law proper to some domains of International Law, such as, inter alia, International Environmental Law".39 These principles of international environmental law include the principle of prevention and precaution. ${ }^{40}$

It follows that the general principles underlying other specific areas of public international law also qualify as such. ${ }^{41}$ These areas would likely include the law of

adequate demonstration of its existence in international law”. G. Gaja, 'General Principles of Law', in Max Planck Encyclopedia of Public International Law, through <www.mpepil.com>, paras. 17-20. Gaja refers in this context to the ICJ's recognition of the principle of uti possidetis iuris in the Frontier Dispute (Burkina Faso v. Republic of Mali), Judgment of 22 December 1986, para. 24 .

37) Finally, Judge Cançado Trindade concludes that "[i]n contemporary International Law, general principles of law find concrete expression not only in foro domestico, but also at international level. There can be no legal system without them. Always keeping their autonomy, they may find expression in other formal "sources" or manifestations of International Law (and not only treaties and custom), even though not listed in Article 38(1)(c) of the ICJ Statute, but nonetheless resorted to by the ICJ in practice." This view is not only based on an analysis of the legislative history of Article 38 Statute of the PCIJ (when the identification of principles of international law was also pursued) but also a selective review of the doctrinal developments as from the 1920s. Case Concerning Pulp Mills on the River Uruguay (Argentina v. Uruguay), 20 April 2010, ICJ, Separate Opinion of Judge Cançado Trindade, I.C.J. Reports 2010, paras. $28 ; 26,29-47$.

38) O. Spijkers, The United Nations, the Evolution of Global Values and International Law (Intersentia, Cambridge, 2011). Spijkers, who defined global values as: "A global value is an enduring, globally shared belief that a specific state of the world, which is possible, is socially preferable, from the perspective of all human beings, to the opposite of the world" (p. 2o) identified peace and security, social progress and development, human dignity, and selfdetermination of peoples as such. $C f$. also the development of the European Union, which qualifies as an autonomous legal order, and which is founded on "the values of respect for human dignity, freedom, democracy, equality, the rule of law and respect for human rights, including the rights of persons belonging to minorities. These values are common to the Member States in a society in which pluralism, non-discrimination, tolerance, justice, solidarity and equality between women and men prevail." (Article 2 of the Treaty on European Union). 39) Argentina v. Uruguay, supra note 37, para. 48.

40) Ibid., paras. 52-96.

41) In the law of the European Union, which arguably qualifies as a specific area of international law, the identification and application of general principles of (EU) law by the Court of Justice of the European Union have reached a level of sophistication similar to that of 
treaties, the law of State responsibility, the law of international organisations or international institutional law (including the law on international administrative procedure/civil service), ${ }^{42}$ international economic law (trade law and investment law), the law of the sea, the law of outer space, international labour law, human rights law, international criminal law ${ }^{43}$ and the law of armed conflict.

Further clarification of the fundamental principles of the law of armed conflict as well as other areas of public international law would have several advantages. It would provide guidance to States for the further development of these areas of public international law; ${ }^{44}$ to judges and arbitrators for the interpretation and application of public international law to a specific dispute; and to lecturers for the teaching of public international law (principles provide for a natural framework to structure a course). Further, the clarification of the fundamental principles of the various areas of public international law would reveal their mutual commonalities (unity within diversity) ${ }^{45}$ and as such clarify the interrelationship between the various areas of public international law. ${ }^{46}$ For example, the principle of military necessity - as one of the principles of the law of armed conflict or ius in bello - appears to be related to the principle of necessity which underlies the right of self-defence under ius ad bellum, and the principle of necessity which underlies the derogation of human rights under the various human rights treaties. And all these manifestations of necessity appear to be linked to the principle of necessity which underlies necessity as a circumstance precluding wrongfulness (reflected in Article 25 of the Articles on State Responsibility). ${ }^{47}$

domestic legal systems. See T. Tridimas, The General Principles of EU Law, 2nd edition (Oxford University Press, Oxford, 2006).

42) See for example, Bustani v. Organisation for the Prohibition of Chemical Weapons (OPCW), ILOAT Judgment 2232, 95th session, 2003, para. 16, in which the Tribunal referred to "the principles on which international organisations' activities are founded" and subsequently to "the general principles of the law of the international civil service".

43) See for example F. O. Raimondo, General Principles of Law in the Decision of International Criminal Courts and Tribunals (Martinus Nijhoff Publishers, Leiden, 2008).

44) Lammers calls this the formative function of the general principles of international law. J. G. Lammers, 'General Principles of Law Recognized by Civilized Nations', in F. Kalshoven et al. (eds.), Essays on the Development of the International Legal Order; In Memory of Haro F. van Panhuys (Sijthoff \& Noordhoff, Alphen aan den Rijn, 1980; in cooperation with the T.M.C. Asser Institute, The Hague) p. 69.

45) Unity within diversity is the subtitle of H. G. Schermers and N. M. Blokker, International Institutional Law, 5th revised edition (Martinus Nijhoff Publishers, Leiden, 2011). Similarly Judge Cançado Trindade who states: "However circumscribed or specialized may one of its domains [be], its basic principles can there be found ..., assuring the cohesion and unity of the Law as a whole." Argentina v. Uruguay, supra note 37, para. 204.

46) Indeed, as the Arbitral Tribunal in Sempra Energy International / Argentina observed: "International law is not a fragmented body of law as far as basic principles are concerned ..." Sempra Energy International v. Argentina, 28 September 2007, ICSID ARB/02/16, Award, para. 378.

47) See T. Gazzini et al., 'Necessity Across International Law: An Introduction', in I. F. Dekker and E. Hey (eds.), 41 Netherlands Yearbook of International Law (2010) pp. 8-10, in which they 
It is suggested that the ILC should include the identification of the general principles of international law and the general principles of the various areas of public international law on its (long-term) agenda. There is no other international body with the knowledge, authority and terms of reference to accomplish such task. It appears, however, that for such task Article 1 of the Statute of the ILC ${ }^{48}$ would have to be amended or reinterpreted. After all, the ILC would not be engaged in the codification or progressive development of international law (which are the objects of the ILC pursuant to Article 1 and which envisage the drafting of specific rights and obligations in treaty format), but with the identification of general principles of international law. 49

Although the general principles of (international) law and the specific rights and obligations flowing from international conventions and international custom are related, it is pertinent to keep a strict distinction between these autonomous sources of international law. After all, principles underlie rules and explain their existence. ${ }^{50}$ Indeed, it would seem "conceptually flawed"51 to see to what extent principles have developed into norms of customary international law and to refer to customary principles of international law. ${ }^{52}$ General principles of law are "guiding principles of general content and, in that, they differ from the norms or rules

introduce the various contributions on the role of necessity across public international law in this special publication of the Netherlands Yearbook. The areas covered are the law on the use of force (Tsagourias), the law of armed conflict (Venturini), human rights law (Ryngaert), international economic law (Qureshi), international investment law (Reinisch), international environmental law (Fitzmaurice), and the law of the European Union (Koutrakos).

48) Statute of the International Law Commission 1947, adopted by the General Assembly by A/RES/174 (II) of 21 November 1947, as most recently amended by A/RES/36/39 of 18 November 1981.

49) It appears that, nowadays, in view of the ever extending corpus of public international law, it is possible to identify the general principles of the various areas of public international law by means of induction, similar to the induction of the principle of ambituity from the existence of Article 35(3) AP I and the customary duty of care for the environment. Induction would guarantee that the general principles of law are abstractions from positive international law and not from natural law. Schwarzenberger also suggests induction as the primary method for the identification of fundamental principles of international law, with deduction as strictly auxiliary. G. Schwarzenberger, 'The fundamental principles of international law', 87 Recueil des Cours (1955-I) pp. 197-198. See also on identification of general principles, among others, O. Elias and C. Lim, 'General principles of law, soft law and the identification of international law', 28 Netherlands Yearbook of International Law (1997). Cf however Judge Cançado Trindade, who is of the opinion that the general principles of law (including the general principles of the various domains of public international law) "emanate from human conscience, the universal juridical conscience, the ultimate material 'source' of all Law”. Argentina v. Uruguay, supra note 37, paras. 191-217, in particular para. 217 .

50) According to Fitzmaurice, "[a] rule answers the question 'what': a principle in effect answers the question 'why'” G. Fitzmaurice, 'The General Principles of International Law; Considered from the standpoint of the rule of law', 92 Recueil des Cours (1957-II) p. 7 .

51) Argentina v. Uruguay, supra note 37, para. 17.

52) According to Schwarzenberger, "[i]f the principle in question is said to be based on international customary law, this terminology easily becomes misleading. It is then an abbreviation for stating more accurately that the principle is an abstraction, and nothing but an abstraction, 
of positive international law, and transcend them".53 They function as "basic pillars of the international legal system" and foundations of the more specific areas of public international law. As explained above, the conventional and customary rules of the law of armed conflict are reflections or manifestations of the fundamental principles of the law of armed conflict. ${ }^{54}$

\subsection{The Principle of Ambituity as a General Principle of Law}

Recognising the fundamental principles of the law of armed conflict, including the principle of ambituity, as general principles of law has not only theoretical but also practical consequences. As a general principle of law, and therefore as an autonomous source of international law, the function of the principle of ambituity is threefold.

First, the principle of ambituity can be used to interpret existing conventional or customary rules of international law, in particular those rules which specifically protect the environment during armed conflict (perhaps by (cross) reference to related principles of international environmental law). If the meaning or scope of specific rights and obligations of belligerents during armed conflict is unclear, the principle of ambituity may be used to provide further legitimacy to a specific interpretation. For example, the principle of ambituity could support the conclusion that Article 35(3) AP I and Article 55 AP I not only protect the natural environment on land, but also the marine environment and the atmosphere. ${ }^{55}$ Further, the principle of ambituity could be used to interpret the rules relating to non-international armed conflict in order to limit the consequences of the conduct of hostilities which are required by the necessities of war.

from a number of rules which themselves bear the hall-mark of this law-creating process." Schwarzenberger, supra note 49, p. 207. It appears that the ICJ's references to the principles of distinction and unnecessary suffering as "cardinal principles contained in the texts constituting the fabric of humanitarian law" and the "intransgressible principles of international customary law" must be interpreted as such. Nuclear Weapons Opinion, supra note 13, paras. 78-79. Please also note that the incorporation of fundamental principles into multilateral treaties may eventually influence the scope and interpretation of a fundamental principle of international law. Schwarzenberger, supra note 49, p. 213.

53) Argentina v. Uruguay, supra note 37, para. 39.

54) According to Judge Gaja a "general principle of law may be embodied in a treaty provision or become part of international customary law". It appears that conceptually, it would have been more appropriate to refer to general principles which are reflected in customary international law rather than becoming part of customary international law. Gaja, supra note 36, para. 24. According to Judge Cançado Trindade, rules of customary and conventional law are inspired by general principles of law. Argentina v. Uruguay, supra note 37, para. 17.

55) See Koppe, supra note 4, pp. 154-167. After all, Article 55 applies to certain aspects of naval and air warfare (see Article 49(3) AP I) and the basic rules on methods and means of warfare as laid down in Article 35 AP I were intended to apply to land, naval and aerial warfare. See International Committee of the Red Cross, Draft Additional Protocols to the Geneva Conventions of August 12, 1949; Commentary (ICRC, Geneva, 1973) p. 54. 
Second, the principle of ambituity can be used to fill any lacunae within the law and thereby supplement the rights and obligations of States during armed conflict. ${ }^{56}$ It is arguable that this supplementary function of the general principles of the law of armed conflict is reflected in the Martens clause, most recently articulated in Article 1(2) AP I: "In cases not covered by this Protocol or by other international agreements, civilians and combatants remain under the protection and authority of the principles of international law derived from established custom, from the principles of humanity and from dictates of public conscience." It appears that this clause, which was originally drafted in 1899 (i.e. before the drafting the Statute of the Permanent Court of International Justice (PCIJ)), recognises the status of the general principle of humanity as an independent source of (international) law, in addition to the relevant conventional and customary rules. ${ }^{57}$ The principle of ambituity could play a similar role as the principle of humanity, not only with respect to international armed conflict, but also with respect to noninternational armed conflict, which currently lacks specific obligations relating to the protection of the environment. ${ }^{58}$

56) See Lammers, supra note 44 , pp. 64-65, 69. Similarly, Elias and Lim, supra note 49, pp. 40-41. Akehurst identified similar functions of equity, namely equity infra legem (adapting the law to the facts in an individual case) and equity praeter legem (supplementary function of equity to fill gaps in the law). M. Akehurst, 'Equity and General Principles of Law', 25 International and Comparative Law Quarterly (1976) pp. 801-806. Similarly, under Dutch civil law the principles of reasonableness and fairness (referred to as 'good faith' before the entry into force of the new Dutch Civil Code in 1992) supplement the rights and obligations of parties under contracts or statutory law. Article 6:2(1) of the Dutch Civil Code (DCC) provides in relation to legal obligations in general (in translation): "Creditors and debtors are obliged to act towards each other pursuant to the standards of reasonableness and fairness." Article 6:248(1) DCC provides in relation to contractual obligations: "A contract does not only have the legal consequences as agreed upon by the contracting parties, but also those, which, considering the nature of the contract, follow from statutory law, custom, or the standards of reasonableness and fairness."

57) This interpretation of the Martens clause appears to be confirmed by De Preux in the Commentary to Additional Protocol I: "Military necessity means the necessity for measures which are essential to attain the goals of war, and which are lawful in accordance with the laws and customs of war. ... Conversely, when the law of armed conflict does not provide for any prohibition, the Parties to the conflict are in principle free within the constraints of customary law and general principles. This is specified in [Article 1(2) AP I]. This is the Martens clause, which was already contained in essentially the same form in the Preamble of Hague Convention IV of 1907. In other words, when the Parties to the conflict do not clash with a formal prohibition of law of armed conflict, they can act freely within the bounds of the principles of international law, i.e., they have the benefit of a freedom which is not arbitrary but within the framework of law." Sandoz et al., supra note 17, para. 1389. This interpretation appears to be rejected by Cassese by reference to the preparatory works in relation to the 1899 Hague Regulations, Martens' original intentions, and practice after 1899. A. Cassese, 'The Martens Clause: Half a Loaf or Simply Pie in the Sky?', 11 European Journal of International Law (2000) pp. 193-212.

58) Indeed it is not easy to distinguish between the interpretative function and the supplementary function of general principles of law. This grey area is also recognised in relation to the functions of the principles of reasonableness and fairness under Dutch law. A. S. Hartkamp and C. H. Sieburgh, Mr. C. Asser's Handleiding tot de beoefening van het Nederlands Burgerlijk 
Third, the principle of ambituity may set aside or modify existing customary and conventional rules under the law of armed conflict. ${ }^{59}$ After all, as a general principle of law, the principle of ambituity qualifies as a primary and autonomous source of international law and the application of such principle of law may lead to a different result than the application of conventional and customary rules of international law. For purposes of legal certainty, however, it is submitted that such application of the principle of ambituity (and of other general principles of law for that matter) must be restricted to exceptional circumstances, for example if the application of conventional or customary rules leads to a result which is manifestly contrary to the object and purpose of the principle of ambituity. ${ }^{60}$ This could mean that a belligerent may still be held responsible for acting contrary

Recht. 6. Verbintenissenrecht. Deel I. De verbintenis in het algemeen, eerste gedeelte (Kluwer, Deventer, 2012) no. 55-59, in particular no. 56; and generally A. S. Hartkamp and C. H. Sieburgh, Mr. C. Asser's Handleiding tot de beoefening van het Nederlands Burgerlijk Recht. 6. Verbintenissenrecht. Deel III. Algemeen overeenkomstenrecht (Kluwer, Deventer, 2010) no. 378-435.

59) Dahm, for example, writes: "Drittens aber haben die Grundsätze des Rechts eine Begrenzungs- und Gewohnheitsrecht zu zwingenden Grundsätzen des Rechts, zu elementaren Forderungen der Gerechtigkeit, zum Naturrecht in Widerspruch setzen, dort können sie nicht zur Anwendung kommen." G. Dahm, Völkerrecht; Band I (W. Kohlhammer Verlag, Stuttgart, 1958), p. 41. And Kolb writes: "General principles of law have an important role also when it comes to the interpretation of legal norms. ... This role of the principles can then go up to a point where the question is not any more one of interpretation, but becomes one of correction of a norm, or even of derogation. Such a derogatory function is visible mainly when it comes to general principles of ius cogens-character, such as the non-recourse to force." Such function was accepted by the umpire in the Mines of Aroa case of 1903. R. Kolb, 'Principles as Sources of International Law (with specific reference to Good Faith)', 53 Netherlands International Law Review (2006) p. 32. Lammers, who calls this 'the corrective function', rejects this function of general principles of law (albeit without explanation), except when principles correct other principles of law or qualifies as a peremptory norm of international law. See Lammers, supra note 44, pp. 65, 69. According to Akehurst, there is unanimous opinion that international tribunals "cannot apply equity contra legem in the absence of an express authorization to apply equity contra legem such as is found in [Article 38(2) ICJ Statute]". Akehurst, supra note 56 , p. 807 .

60) It appears that such application of the principles of the law of armed conflict was (implicitly) confirmed by the ILC when it stated that specific rules of the law of armed conflict must not apply when the necessities of war (or the principle of necessity) are absent. After all, if certain conduct is not justified by the necessities of war (which is "the underling criterion for a whole series of substantive rules of the law of war and neutrality") "the general rule of the law of peace prohibiting certain actions again prevails". This implies that all conduct during armed conflict must also and in last resort be assessed by the necessities of war (given by the object and purpose of warfare namely to weaken the military forces of the enemy). A/CN.4// SER.A/1980/Add.1 (Part 2), Yearbook of the International Law Commission, 1980, Vol. II, Part Two, supra note 11, pp. 45-46. Similarly N. Melzer, Targeted Killing in International Law (Oxford University Press, Oxford, 2008) pp. 286-289. Because of the same reason, the principle of military necessity cannot be used to justify conduct which is contrary to customary or conventional obligations under the law of armed conflict (Kriegsraison geht vor Kriegsmanier). See Sandoz et al., supra note 17 , para. 1389 . Similarly Venturini, supra note 20 , pp. $5^{1-52 . ~ S u c h ~ a r g u m e n t ~ i s ~ t h e ~}$ exact opposite of the also conceptually wrong since it implies that the principle of military necessity can also trump other fundamental principles of the law of armed conflict. 
to the principle of ambituity even if his acts were for some reason not contrary to its above-mentioned conventional or customary obligations. ${ }^{61}$

\section{The Prohibition Against Excessive Collateral Damage to the Environment during Armed Conflict}

\subsection{Introduction}

As noted above, the only legitimate object of warfare is to weaken the military forces of the enemy. This object and purpose is embodied in the general principle of military necessity. It follows that the civilian population and civilian objects may not be the object of attack and that any unintentional or collateral damage to the civilian population or civilian objects should be prevented. The former is embodied in the general principle of distinction; the latter is embodied in the general principle of proportionality.

Although it appears to be generally accepted that excessive collateral damage to the environment during armed conflict is prohibited, the legal basis for such prohibition is not self-evident. It is submitted that this prohibition does not follow from Additional Protocol I (section 3.2), but from custom (section 3.3). The scope of this prohibition is subsequently discussed in section 3.4 .

\subsection{The Alleged Prohibition Against Excessive Collateral Damage to the Environment Under Additional Protocol I}

The general principle of proportionality is reflected in the prohibition against excessive collateral damage to the civilian population and civilian objects as recognised in treaty law and customary international law. Articles 51(4) and (5)(b) AP I, for example, provide: "Indiscriminate attacks are prohibited. ... Among others, the following types of attacks are to be considered as indiscriminate: ... (b) an

61) As such the general principle of ambituity (or any other general principle of law for that matter) would resemble the scope and functioning of the above-mentioned general principles of reasonableness and fairness in Dutch civil law. In particular, the so-called derogatory or restrictive effect of these principles may entail that contractual or even statutory rights and obligations are not applicable in a specific case, if the application of those rights and obligations would be, under the specific circumstances, unfair and unreasonable. Article 6:2 DCC provides, in relation to legal obligations (in translation): "A rule which is applicable between [creditor and debtor] pursuant to statutory law, custom or legal act, is not applicable, to the extent that this would be, under the specific circumstances, unacceptable pursuant to the standards of reasonableness and fairness." Article 6:248(2) DCC provides, in relation to contracts: "A rule which is applicable between parties pursuant to a contract, is not applicable to the extent that this would be, under the specific circumstances, unacceptable pursuant to the standards of reasonableness and fairness." 
attack which may be expected to cause incidental loss of civilian life, injury to civilians, damage to civilian objects, or a combination thereof, which would be excessive in relation to the concrete and direct military advantage anticipated." ${ }^{\prime 2}$ According to the ICRC, both provisions reflect customary international law. Rule 14 of its CIHL Study provides: "Launching an attack which may be expected to cause incidental loss of civilian life, injury to civilians, damage to civilian objects, or a combination thereof, which would be excessive in relation to the concrete and direct military advantage anticipated, is prohibited."

The law of armed conflict defines civilian objects as those objects which do not qualify as military objects. Military objects are objects which "by their nature, location, purpose or use make an effective contribution to military action and whose total or partial destruction, capture or neutralisation, in the circumstances ruling at the time, offers a definite military advantage" (Article 52(2) AP I and Rule 8 CIHL Study). Therefore, if elements of the environment do not make an effective contribution to military action, these elements would qualify as a civilian object under the laws of armed conflict. ${ }^{63}$ This conclusion is confirmed by the positioning of Article 55 AP I in Chapter III of Section I of Part IV of Additional Protocol I, which is titled 'Civilian Objects' ${ }^{64}$

It follows, at first sight, that because of this qualification as a civilian object, the environment is ipso facto protected against direct attack and against excessive collateral damage as an ordinary civilian object under Additional Protocol I.65 This position is taken by various authors, including Bothe, Bruch, Diamond and Jensen. In a recent publication in the International Review of the Red Cross they state: "Elements of the environment are most often civilian objects. As such, they

62) Further, Articles 57 and 58 AP I require parties to a conflict to take certain precautionary measures in the conduct of military operations to spare the civilian populations, civilians and civilian objects. See also Rules 15-24 CIHL Study.

63) Please note, however, that the formulation of Article $8(2)(\mathrm{b})(\mathrm{iv})$ of the Rome Statute conflicts with this view. Article 8(2)(b)(iv) qualifies, as a war crime, the international launch of an attack "in the knowledge that such attack will cause incidental loss of life or injury to civilians or damage to civilian objects or widespread, long-term and severe damage to the natural environment ...", thereby distinguishing between civilian objects and the natural environment.

64) Similarly Y. Dinstein, The Conduct of Hostilities under the Law of International Armed Conflict, 2nd edition (Cambridge University Press, Cambridge, 2010) p. 204. Please note, however, that the scope of Part IV of AP I is generally limited to civilian objects on land pursuant to Article 49(3) AP I. This limitation arguably does not apply to the protection of civilian objects under customary international law, nor does it apply to the protection of the natural environment under Article 35(3) AP I. See Koppe, supra note 4, pp. 154-167.

65) It is exactly for this reason that Heintschel von Heinegg and Donner conclude that the natural environment does not or rather cannot qualify as a civilian object. Furthermore, they are of the opinion that civilian objects are limited to "material things that can be seen or touched. The natural environment as the sum total of different and differing natural components and processes may not be characterizes as such an object." W. Heintschel von Heinegg and M. Donner, 'New Developments in the Protection of the Natural Environment in Naval Armed Conflicts', 37 German Yearbook of International Law (1994) pp. 288-289. 
are protected against attacks. To that extent, the restrictive conditions of Articles 35 and 55 of Additional Protocol I do not apply. This protection is, however, shaky, as environmental elements can easily become military objectives." 66

Substantively, the consequence of this approach is that the scope of Article 55 AP I (and Article 35(3) AP I for that matter) is limited to circumstances when the environment indeed qualifies as (or rather becomes) a military object or when any collateral damage to the environment would be justified by the military advantage to be obtained. Such damage to the environment would then generally be permitted under Additional Protocol I unless the damage is widespread, long-term and severe.

Practically, the consequence of this approach is that the legality of a(n) (planned) attack which may involve damage to the environment must first be assessed by reference to Articles $5^{1}$ and $5^{2} \mathrm{API}$ (and their customary equivalents), and subsequently by reference to Article 55 AP I.

Schematically, an ex post facto assessment of the legality of an attack would look as follows:

1. Qualification of the target (the environment) as a civilian or military object (Article 52 AP I).

2. If the target (the environment) qualified as a military object, then the following would apply.

a. The attack was lawful as a matter of principle (Article $5^{2}$ AP I), unless the intended or expected damage to the target (the environment) was widespread, long-term and severe and prejudiced the health or survival of the population (Article 55 AP I).

3. If the target (the environment) qualified as a civilian object, then the following would apply.

a. The attack was unlawful as a matter of principle (Article $5^{2}$ AP I). However, if the environment was not targeted as such and the damage to the environment qualifies as acceptable (not-excessive) collateral damage, the attack would nevertheless be lawful (Article 51) unless the intended or expected damage was widespread, long-term and severe and prejudiced the health or survival of the population (Article 55 AP I).

It is submitted, however, that the better reading of the interrelationship between Articles $51 / 5^{2}$ and 55 AP I is that Article 55 AP I specifies the protection of the

66) M. Bothe et al., 'International law protecting the environment during armed conflict: gaps and opportunities', 92 International Review of the Red Cross (2010) p. 576. See also M. Bothe, 'The Protection of the Environment in Times of Armed Conflict; Legal Rules, Uncertainty, Deficiencies, and Possible Developments', 34 Germany Yearbook of International Law (1991) p. 55. Also Dinstein stipulates that "once classified as a civilian object, the natural environment must not be the object of attack". Dinstein, supra note 64, p. 204. 
environment as a civilian object and thereby supplants the general protection provided by Articles 51/52 AP I. It follows that the environment does not enjoy or can no longer enjoy such general protection as a civilian object under Additional Protocol I and that the legality of any (planned) attack involving (possible) damage to the environment must be assessed by reference to Article 55 AP I only and by reference to Article 55 AP I alone.

Schematically, an ex post facto assessment would then look as follows:

1. Qualification of the damaged object as (elements of) the environment.

2. If the damaged object qualifies as (elements of) the environment, then the attack was unlawful as a matter of principle provided that:

a. the attack caused widespread, long-term and severe damage to the environment thereby prejudicing the health or survival of the population; and

b. the attack was intended or expected to cause such damage (Article 55 AP I).

This reading is based on the fact that the drafters of Additional Protocol I chose to include a specific provision on the protection of the environment during international armed conflict in the Protocol's chapter dealing with civilian objects, which would provide for specific protection to the environment under specific and exceptional circumstances. ${ }^{67}$ The introduction of Article 55 AP I (and Article 35(3)

67) Similar provisions were included for cultural objects (Article 53 AP I), places of worship (Article 53 AP I), objects which are indispensable for the survival of the civilian population (Article 54 AP I) and installations which contain dangerous forces (Article $5^{6}$ AP I), although their interaction with Article 52 AP I is not self-evident either. In particular the scope of Article 53 AP I (cultural property and places of worship) is subject of discussion. Article 53 AP I does not contain a military necessity exception clause (as do Articles 54 and 56 API, which suggests, by reference to the general maxim and interpretation technique expressio unius est exclusio alterius, that the protection of Article 53 AP I is absolute, even if the object is used for military purposes and therefore would qualify as a military object. Such interpretation, however, is not accepted, either because of the reference to the 1954 Hague Convention and other relevant international instruments in the chapeau of Article 53, which are not prejudiced by Article 53, or because of its interaction with Article 52(2) AP I. The former argument is persuasive but only in so far states parties to these instruments are involved. See, for example, Kolb and Hyde, supra note 9, p. 146. The latter argument appears to be less persuasive, but accepted in the ICRC Commentary to Article 53, Sandoz et al., supra note 17, paras. 2072 and 2079. Similarly M. Bothe et al., New Rules for Victims of Armed Conflicts; Commentary on the Two 1977 Protocols Additional to the Geneva Conventions of 1949 (Martinus Nijhoff Publishers, The Hague, 1982) pp. 333-334 (referring to the understanding of several Western delegations, and stipulating that an attack must first be assessed by reference to Article 52 AP I and only after meeting this "two-pronged test" by reference to Article 53 AP I). The latter view is also upheld by O'Keefe: "That said, if and for as long as an object covered by article 53 is used in support of the military effort contrary to paragraph (b), the legality of any attack against that object - and only that object - falls to be determined by reference to article $5^{2}(2)$, and will be lawful provided such use makes an effective contribution to military action and the object's total or partial destruction, capture or neutralisation, in the circumstances ruling at the time, offers a definite military advantage." 
AP I for that matter) did not follow from prior dissatisfaction with the protection of the environment during international armed conflict under the general rules on the protection of civilian objects. There was no attempt to create more legal certainty for military policy makers as to what they could and could not do during hostilities because the general rules on protection of civilian objects provided insufficient guidance.

On the contrary, the idea that the environment had to be protected during international armed conflict was new in public international law. Indeed, a general concern for the protection of the environment in general only emerged in the 1960 s and was highlighted by the above-mentioned 1972 Stockholm Declaration. The inclusion of specific provisions on the protection of the environment during international armed conflict in Additional Protocol I was therefore exceptional and progressive.

The conference records of the Diplomatic Conference show that the drafters indeed intended to raise a high threshold for responsibility for damage to the environment during international armed conflict. Only the use of means or methods of warfare intended or expected to cause widespread, long-term and severe damage to the environment was considered wrongful. It appears that this cumulative standard was deliberately included to make sure that responsibility for environmental damage would be exceptional and that a tank commander whose tank flattened a tree would not be made a war criminal. ${ }^{68}$ Without reference to the general protection of civilian objects under current Articles $5^{1}$ and $5^{2}$ AP I, "[i]t appeared to be a widely shared assumption that battlefield damage incidental to conventional warfare would not normally be proscribed by this provision". 69

Further, it appears that the drafters intended the specific provisions relating to the protection of the environment to be the only rules which would provide such protection, irrespective of the question whether or not the environment qualified as a military or civilian object. There is no indication in the text of Additional Protocol I nor in the preparatory works that the environment is generally protected as a civilian object under Articles 51 and $5^{2} \mathrm{AP}$ I. There is no indication that Article 55 was thus intended to complement or supplement Articles $5^{1}$ and $5^{2}$ of Additional Protocol. And there is no indication that any assessment of damage to the environment would first have to be assessed by reference to the general rules of Articles $5^{1}$ and 52 AP I or that one could fall back on either of these two general provisions when the criteria of Article 55 would not be met.

R. O'Keefe, The Protection of Cultural Property in Armed Conflict (Cambridge University Press, Cambridge, 2006) p. 216.

68) Levie, supra note 2, pp. 130, 272.

69) Report of Committee III, Second Session (CDDH/215/Rev 1), in H. S. Levie, Protection of War Victims: Protocol 1 to the 1949 Geneva Conventions, Volume 2 (Oceana Publications, Dobbs Ferry, NY, 1980) pp. 276-277. 
As a matter of fact, the link between the environment and civilian objects and the civilian population was not self-evident during the negotiations for Additional Protocol I. It was only decided in 1975 that Additional Protocol I would contain two separate provisions on the protection of the environment: one provision in the section on basic rules on means and methods of warfare protecting the environment per se and therefore characterised as eco-centric; and one provision in the section on the protection of civilian objects protecting the environment as an object which is necessary for the health and survival of the civilian population, and therefore characterised as anthropocentric. ${ }^{70}$

It follows that Article 55 AP I (and Article 35(3) AP I for that matter) was intended to be a stand-alone provision, providing for specific protection to the environment and that it must be interpreted as such. The legality of any (intended) attack under Additional Protocol I must therefore be assessed by reference to this provision first and by reference to this provision alone. This holds true, even though, in hindsight, Articles $5^{1}$ and $5^{2}$ AP I could have been a more effective basis for protecting the environment during armed conflict than Article 55 (and 35(3)) AP I. ${ }^{71}$

This interpretation of the relationship between Article 55 and Articles 51 and $5^{2}$ AP I appears to be confirmed in practice. The Special Committee established by the Prosecutor of the International Criminal Tribunal for the Former Yugoslavia (ICTY) to investigate the bombings by the North Atlantic Treaty Organization (NATO) over Yugoslavia in 1999 discussed the possible damage to the environment first by reference to Articles 35(3) and 55 AP I as these were the "basic legal provisions applicable to protection of the environment in armed conflict". ${ }^{72}$ The Committee first stated that "it would appear extremely difficult to develop a prima

70) Levie, supra note 2, pp. 269 et seq.; Sandoz et al., supra note 17, para. 1449.

71) Indeed, the drafters of the 2009 UNEP report on environmental protection during armed conflict wrote: "The provisions that govern the protection of civilian objects and property could provide a more effective legal basis for protecting the environment during armed conflict than those protecting the environment per se, at least under existing IHL treaty law." They subsequently refer the 1907 Hague Regulations, the 1949 Geneva Convention IV and both 1977 Additional Protocols. United Nations Environment Programme, Protecting the Environment During Armed Conflict; An Inventory and Analysis of International Law, UNEP, Nairobi, 2009, p. 16. Verwey noted that indeed, the drafting of Articles 35(3) and 55 AP I may "very well result in lowering traditional standards of protection, for, the cumulative triple standard may now render permissible what before would have been forbidden". W. D. Verwey, "Protection of the Environment in Times of Armed Conflict: In Search of New Legal Perspective', 8 Leiden Journal of International Law (1995) p. 11. Bothe and Schmitt, however, stipulate that Articles 35(3) and 55 AP I were not intended to lower the general rules on the protection of civilian objects. Bothe, supra note 66, p. 56; M. N. Schmitt, 'Green War: An Assessment of the Environmental Law of International Armed Conflict', 22 Yale Journal of International Law (1997) p. 73. This argument fails to convince, however, since the protection of the environment as such was of no state's concern before 1974-1977, and specific rules on the protection of the environment were only included on the basis of the given criteria.

72) International Criminal Tribunal for the Former Yugoslavia (ICTY), 'Final Report to the Prosecutor by the Committee Established to Review the NATO Bombing Campaign against the Federal Republic of Yugoslavia', 39 International Legal Materials (2000) para. 14. 
facie case upon the basis of these provisions, even assuming they were applicable" and concluded that "the environmental damage caused during the NATO bombing campaign does not reach the Additional Protocol I threshold". ${ }^{73}$ Subsequently, the Committee assessed the alleged environmental effects of the NATO bombing campaign by reference to the general principles of necessity and proportionality, since the environmental effects "are best considered from [these] underlying principles of the law of armed conflict". ${ }^{74}$

The Committee did not assess the damage by reference to Articles 51 and $5^{2} \mathrm{AP}$ I as an alternative to Article 55, but instead relied on the underlying fundamental principles of necessity and proportionality (thereby confirming the autonomous status of the above-mentioned general principles of the law of armed conflict) and, so it appears, on the customary rules (prohibition to cause wanton destruction and excessive collateral damage) which reflect both principles. This approach is similar to the approach advocated by the present author, as will be explained further below.

Further, this interpretation of the relationship between Article 55 and Articles $5^{1}$ and $5^{2}$ AP I is confirmed by Heintschel von Heinegg and Donner who are of the opinion that in times of armed conflict the environment is only protected by Articles 35(3) and 55 AP I and therefore only against effects that are widespread, long-term and severe:

Methods and means of (naval) warfare always have negative effects on the environment. The States parties to AP I can, therefore, not be said to have agreed upon a general protection of the environment against negative effects of warfare. ... Finally, it would be difficult to explain why the drafters of AP I did not simply state that the term "civilian object" also comprises the environment. Instead they agreed on two independent provisions that will protect it only against damages that are 'widespread, long-term and severe. ${ }^{75}$

The upside of having such a specific provision on the protection of the environment is that it provides absolute protection to the environment (including collateral damage) even when its use would have military advantages and would support military operations. The downside of having such a specific provision on the protection of the environment, however, is that it appears to be the only protection provided to the environment as a civilian object under Additional Protocol I, and

73) Ibid., para. 17.

74) Ibid., paras. 18-25. Please note, however, that the committee's reference to A. P. V. Rogers, 'Zero Casualty Warfare', 82 International Review of the Red Cross (2000) pp. 177-178, in para. 18 is incorrect. First, the committee appears to refer to Rogers' citation of a particular section in the British Defense Doctrine, which cannot be attributed to Rogers. Second, this particular quote from the British Defense Doctrine does not refer to collateral damage to the environment (as suggested by the Committee) but generally to collateral damage to civilians and civilian objects.

75) Heintschel von Heinegg and Donner, supra note 65, p. 289. 
that the practical application of Article 55, in view of its high threshold, appears to be limited.

\subsection{The Prohibition against Excessive Collateral Damage to the Environment under Customary International Law}

That does not mean that there is no additional protection to the environment during international armed conflict additional to Articles 35 and 55 AP I. As mentioned in section 1, it is arguable that since the early 1990s three rules of customary international law have emerged, including a specific prohibition against excessive collateral damage to the environment during international armed conflict. ${ }^{76}$ This rule follows from the general principles of proportionality and ambituity and complements the conventional and customary prohibitions against excessive collateral damage to civilian objects.

The emergence of this specific prohibition is evidenced in State practice, such as the drafting of Article 8(2)(b)(iv) of the Rome Statute, which provides for individual responsibility for causing excessive environmental damage during international armed conflict. Pursuant to Article 8(2)(b)(iv) an intentional attack "in the knowledge that such attack will cause incidental loss of life or injury to civilians or damage to civilian objects or widespread, long-term and severe damage to the environment which would be clearly excessive in relation to the concrete and direct overall military advantage anticipated" qualifies as a war crime. Although inspired by Articles 35(3) and 55 AP I, the text of Article 8(2)(b)(iv) clearly joins in with the customary prohibition to cause excessive collateral damage to civilian objects and the civilian population as reflected in Articles 51(5)(b) AP I. Article $8(2)$ (b)(iv) introduces a similar balancing test which is absent in the text of Articles 35(3) and 55 AP I. According to the drafters of the Rome Statute, this particular war crime qualifies as "a serious [violation] of the laws and customs applicable in international armed conflict, within the established framework of international law" (chapeau Article 8(2)(b) Rome Statute), which suggests the existence of a customary prohibition against causing excessive collateral damage to the environment.

Further evidence and inferences can be found in the United States Commander's Handbook on the Law of Naval Operations, ${ }^{77}$ and public statements made by State representatives in public memorandums or within the framework of the General Assembly or before the International Court of Justice (usually referring to both

76) The other two rules are the prohibition against wanton destruction to the natural environment and a general duty of care for the natural environment during international armed conflict. See Koppe, supra note 4, pp. 246-278.

77) NWP 1-14M, The Commander's Handbook on the Law of Naval Operations, Department of the Navy (Newport, RI, 2007), through <www.nwc.navy.mil >, para. 8.4. 
the prohibition of wanton destruction of the environment and the prohibition against excessive collateral damage together). Canada, for example, stated in 1992:

An important evolution was thus taking place which reflected the importance of the ecological point of view and which should be brought to bear on other questions, such as that of proportionality (the need to strike a balance between the protection of the environment and the needs of war) or that of the distinction between military and nonmilitary objectives. Under the same principle, the environment as such should not be the object of direct attack, and his delegation would like to see that point reflected in the resolution to be adopted after discussion of the item. ${ }^{78}$

Additionally, the 1994 San Remo Manual on International Law Applicable to Armed Conflicts at Sea, ${ }^{79}$ the 1993 ICRC Guidelines ${ }^{80}$ and the 1999 ICRC Model Manual on the Law of Armed Conflict, ${ }^{81}$ each include, in so many words, a prohibition against causing excessive collateral damage to the environment.

Finally, the existence (or emergence) of a customary prohibition against causing excessive collateral damage to the environment has been acknowledged in literature ${ }^{82}$ and confirmed by the ICRC in 2005 in its Study on Customary International Humanitarian Law. Customary Rule $43 \mathrm{C}$ comprehensively provides: "Launching an attack against a military objective which may be expected to cause incidental damage to the environment which would be excessive in relation to the concrete and direct military advantage anticipated is prohibited."

It is submitted that this relatively new rule of customary international law complements Articles 35 and 55 AP I (i.e. for States parties to AP I). The customary prohibition emerged later in time (arguably in the 1990s) and States were fully

78) A/C.6/47/SR.8, Summary Record of the 8th meeting of the Sixth Committee of the General Assembly on 1 October 1992, p. 6, para. 20. For more references, see Koppe, supra note 4, pp. 264-268.

79) San Remo Manual on International Law Applicable to Armed Conflicts at Sea, in International Review of the Red Cross (1995), No. 309, para. 46(d) and 13(c).

80) A/48/269, Report of the Secretary-General to the General Assembly on the Protection of the Environment in the Environment in Times of Armed Conflict, of 29 July 1993, with Annexed the ICRC Guidelines for Military Manuals and Instructions on the Protection of the Environment in Times of Armed Conflict, principle 4.

81) A. P. V. Rogers and P. Malherbe, Fight it Right; Model Manual on the Law of Armed Conflict for Armed Forces (International Committee of the Red Cross, ICRC, Geneva, 1999) para. 702(e) and (f).

82) Heintschel von Heinegg, Donner, supra note 65, p. 294; J.-M. Henckaerts, 'Towards Better Protection for the Environment in Armed Conflict: Recent Developments in International Humanitarian Law', 9 Review of European Community and international environmental law (2000) p. 18; L. Lijnzaad and G. J. Tanja, 'Protection of the Environment in Times of Armed Conflict: The Iraq-Kuwait War', 40 Netherlands International Law Review (1993) p. 184; M. Bothe, 'Protection of the Environment in Times of Armed Conflict', in N. Al-Nauimi and R. Meese (eds.), International Legal Issues Arising Under the United Nations Decade of International Law; Proceedings of the Qatar International Law Conference '94 (Martinus Nijhoff Publishers, The Hague, 1995) p. 98. 
aware of the existence of Articles 35 and 55 AP I at that time. Further, the customary rule appears to provide relative protection to the environment (depending on the military interests involved) whereas Articles 35(3) and 55 provide absolute protection, even if the customary prohibition against excessive collateral damage would not be breached. This would mean that any military action which causes damage to the environment would first have to be assessed under this relatively new customary prohibition; and subsequently, if no breach can be established and if applicable, by reference to Articles 35(3) and $55 \mathrm{AP} \mathrm{I}$.

Schematically, an ex post facto assessment of the legality of an attack would then look as follows:

1. Qualification of the damaged object as (elements of) the environment.

2. If the damaged object qualifies as (elements of) the environment, then the attack was unlawful as a matter of principle provided that:

a. the damage to the environment was collateral; 83 and

b. the damage to the environment was excessive in relation to the concrete and direct military advantage anticipated (customary prohibition against excessive collateral damage to the environment).

3. In the alternative (in case the damaged object qualifies as (elements of) the environment and the damage to the environment is not excessive in relation to the concrete and direct military advantage anticipated), the attack was unlawful as a matter of principle provided that:

a. the attack caused widespread, long-term and severe damage to the environment thereby prejudicing the health or survival of the population; and

b. the attack was intended or expected to cause such damage (Article 55 AP I).

The result of such ex post facto assessment of the legality of an attack causing damage to the environment will be similar to an assessment on the basis of the method advocated by those who argue that the environment is also protected by Articles $5^{1}$ and $5^{2}$ AP I as discussed above. However, the methodology and approach are different (reliance on the relatively new customary prohibition against excessive collateral damage to the environment rather than on Articles 51 and $5_{2} \mathrm{AP}$ I) and based on a more persuasive interpretation of Additional Protocol I.

83) As was mentioned above, willful or wanton destruction of the natural environment during armed conflict is also prohibited under customary international law. This rule of customary international law arguably emerged in the 1990 s and its existence has been confirmed by the ICRC in its CIHL Study (Rule 43). Koppe, supra note 4, pp. 256-278. This contribution deals with the prohibition of excessive collateral damage to the natural environment. 


\subsection{The Scope of the Prohibition Against Excessive Collateral Damage to the Environment}

Finally, the scope of the prohibition against excessive collateral damage to the environment and therefore the responsibility for breach of this prohibition will depend on two factors. First, responsibility for breach of this prohibition will depend on the assessment of the damage to the environment. Second, responsibility for breach will depend on the foreseeability (and thus the expectation) of this damage to those who decide to launch an attack. Only then will it be possible to establish whether or not the damage to the environment was excessive in relation to the military advantage obtained.

As to the assessment of the damage to the environment, it is necessary that the damage to the environment has actually materialised. Contrary to damage to civilians and civilian objects, which is generally immediately visible, damage to the environment may only materialise after some time. Indeed, Verwey recognised that

many interactive natural processes have not yet been (fully) understood, resulting in the fact that harmful effects which are not (yet) recognized or expected may occur now or in the future. Only quite recently, science has become able to demonstrate that even apparently restricted, relatively short-term and seemingly insignificant forms of environmental impact may subsequently turn out to have triggered serious or significant ecological disruption. ${ }^{84}$

Therefore, the assessment of any damage to the environment may take time and thus it may also take time before the responsibility of a wrongdoer can be established. This phenomenon is not uncommon in domestic law, where health damage resulting from smoking, asbestos or other toxic substances may materialise years after the wrongful act was committed. Although this may be undesirable for belligerents who wish to settle any responsibilities and damages after a conflict as soon as possible, it is inevitable due to the nature of the damage. It therefore follows that there may be circumstances under which the responsibility for causing excessive collateral damage to the environment (or widespread, long-term and severe damage under Articles 35 and 55 AP I) may be established years after the conflict has ended.

As to the foreseeability of possible damage to the environment, it appears that such would have to be assessed on the basis of objective criteria and on the basis of the information available to the relevant commander at the time of the attack. ${ }^{85}$

\footnotetext{
84) Verwey, supra note 71, p. 12.

85) Both the United Kingdom and France made such declaration upon ratification of Additional Protocol I on 28 January 1998 and 11 April 2001 respectively. As to the scope of Articles 35(3) and 55 AP I they stated that the risk of environmental damage would have to be assessed objectively and on the basis of the information available at the time. Declarations and reservations
} 
This means that it must be established that the relevant commander knew or should have known that the attack and the means and methods used would cause excessive collateral damage to the environment. If it cannot be established that the relevant commander could reasonably have known that the attack and the means and methods used would cause such damage to the environment, the damage was not foreseeable and responsibility cannot be established. ${ }^{86}$

It follows that increasing knowledge about natural process and the impact of military activities on ecological processes in the long term will therefore increase the scope of this prohibition. ${ }^{87}$ It is therefore suggested that environmental experts and biologists should further investigate the consequences of warfare on the environment and make this knowledge publicly available. Furthermore it is suggested that environmental experts and biologists assume the responsibility to further explain to the military the nature of environmental processes and the sensitivities of ecological systems. While it appears that there is a fruitful dialogue between the military and humanitarian organisations, in particular the ICRC, such dialogue appears to be absent between the military and environmental organisations. The more people know about the environment, the higher the standards of what is expected of the military, and the better the protection of the environment against collateral damage, will be. There is still a world to gain in that respect.

\section{Summary and Conclusions}

The need to protect the environment during armed conflict has generally been recognised by the international community. Prior to 2012, the various United Nations conferences on the environment and sustainable development repeatedly expressed concern for the environment and the General Assembly even proceeded, in 2001, to declare 6 November of each year the 'International Day for Preventing the Exploitation of the Environment in War and Armed Conflict'. The need to protect the environment has further become evident in practice after the use of Agent Orange in Vietnam, the burning of oil wells in Kuwait and massive oil spills in the Persian Gulf and the Mediterranean Sea.

of States Parties to Additional Protocol I available in the ICRC International Humanitarian Law database through $<$ www.icrc.org $>$.

86) Similar standards are generally accepted for foreseeability of damage in relation to Articles 35(3) and 55 AP I. See M. Bothe, 'War and Environment', in R. Bernhardt (ed.), Encyclopaedia of Public International Law; Volume Four; Quirin, Ex Parte to Zones of Peace (Elsevier, Amsterdam, 2000) p. 1344; Dinstein, supra note 64, p. 183.

87) It is even arguable that - in view of the above-mentioned conventional (first sentence Article 55 AP I) and customary duty of care of belligerents for the natural environment during armed conflict - states are required to do active research and obtain information on the likely consequences for the environment of military activities. 
Although the consequences of warfare have proven to be disastrous, attention on the relevant rules protecting the environment during armed conflict has been relatively modest. Furthermore, and in the absence of judicial decisions in this area, opinions differ as to the scope and the adequacy of the existing legal framework. It is therefore significant that the ILC decided in 2011 to include the protection of the environment in relation to armed conflicts in its long-term programme of work. As suggested by Marie Jacobsson, the aim of the ILC's work in this area should include the identification of "new developments in case law or in customary law"; the clarification of "the relation between existing treaty law and new legal developments (including legal reasoning)"; "the formulation of applicable rules and ... principles of general international law of relevance for the topic"; and suggestions "to achieve a uniform and coherent system" in this area. ${ }^{88}$

This article has attempted to contribute to the ILCs work in this area. First it clarified the foundations of the existing legal framework in relation to the protection of the environment during armed conflict. Second it clarified the basis for and scope of the prohibition against excessive collateral damage to the environment during armed conflict.

As to the foundations of the existing legal framework, it is submitted that current conventional and customary rules of armed conflict (entailing specific obligations for belligerent States) which protect the intrinsic value of the environment during armed conflict cannot be deduced from the four fundamental principles of the law of armed conflict: the principles of military necessity, distinction, proportionality and humanity. In order to explain the existence of specific obligations in this area, it is therefore submitted that they follow from a new fundamental principle of the law of armed conflict: the principle of ambituity. Similar to the principle of humanity, the principle of ambituity provides for an absolute limitation to the necessities of war. Article 35(3) AP I is a pure reflection of the principle of ambituity, as is the customary duty of care which belligerent States must observe during armed conflict which arguably emerged in the 1990s. Other rules which aim to protect the environment during armed conflict, such as the prohibition of wanton or excessive collateral damage to the environment, are reflections of a compromise between the principle of ambituity and the principles of distinction or proportionality.

It is further submitted that the fundamental principles of the law of armed conflict, including the principle of ambituity, qualify as general principles of law in the sense of Article 38(1)(c) Statute. Although the general principles of law were traditionally understood as referring to general principles of domestic law common to all legal systems, there is increasing recognition that the general principles

88) A/66/10, Report of the International Law Commission; Sixty-third session (26 April - 3 June and 4 July - 12 August 2011); Annex E - Protection of the environment in relation to armed conflicts (Ms. Marie G. Jacobsson), para. 31. 
of law also include general principles of international law, including principles of specific areas of international law. As such, the fundamental principles of the law of armed conflict would also qualify as general principles of law.

As an autonomous source of international law, the general principle of ambituity and the other fundamental principles of the law of armed conflict may be used to interpret existing conventional or customary rules of international law (perhaps by (cross) reference to related principles of international environmental law) or to fill any lacunae within the law and thereby supplement the rights and obligations of States during armed conflict. Further it is not impossible that, under specific circumstances, the principle of ambituity may be applied in deviation of conventional or customary rules of international law. This could mean that, under exceptional circumstances, the application of this principle could in itself determine the rights and obligations of belligerents during armed conflict, including those articulated in Articles 35(3) and 55 AP I, and the customary prohibitions of wanton and excessive collateral damage to the environment and the customary duty of care for the environment during armed conflict.

As to the basis and scope of the specific prohibition against excessive collateral damage to the environment during armed conflict, it is submitted that this prohibition cannot be based on Articles $5^{1}$ and $5^{2}$ AP I. On the basis of a contextual interpretation of Article 55 AP I and in light of the legislative history of Article 55 AP I and 35(3) AP I, it is submitted that Article 55 AP I was intended to be a standalone provision, providing for specific protection to the environment, and specifying the general protection of the environment as a civilian object under Articles $5^{1}$ and $5^{2}$ AP I. It follows that the legality of any (intended) attack under Additional Protocol I must therefore be assessed by reference to this provision first and by reference to this provision alone. This holds true even though, in hindsight, Articles $5^{1}$ and $5^{2}$ AP I could have been a more effective basis for protecting the environment during armed conflict than Article 55 (and 35(3)) AP I.

Instead the prohibition against excessive collateral damage follows from a relatively new rule of customary international law, which arguably emerged in the 1990s. It is submitted that this relatively new rule of customary international law complements Articles 35 and 55 AP I (i.e. for States parties to AP I). Further, in view of the scope of this prohibition, and since it emerged later in time, it is submitted that any military action which causes collateral damage to the environment would first have to be assessed under this relatively new customary prohibition; and subsequently if no breach can be established and if applicable by reference to Articles 35(3) and 55 AP I.

Finally, it has been explained that environmental damage may materialise long after the conflict has ended and that the prohibition against excessive collateral damage to the environment essentially depends on the knowledge of military commanders and decision-makers of environmental processes. It is therefore suggested to further investigate the consequences of warfare on the environment 
and that environmental experts and biologists make this knowledge publicly available and explain their findings to the military. The more people know about the environment, the higher the standards of what is expected of the military, and the better the protection of the environment against collateral damage, will be.

In relation to the above-mentioned aims of a possible study of the ILC on the protection of the environment in relation to armed conflict, it is suggested that the ILC should include and consider in its discussions the meaning and scope of the fundamental principles of the law of armed conflict, in particular the emergence of the principle of ambituity. It is further suggested that the ILC should clarify the relationship between these fundamental principles and the conventional and customary rules which protect the environment during armed conflict and consider the argument made here that these fundamental principles qualify as general principles of law in the meaning of Article 38(1)(c) Statute. Finally, it is suggested that the ILC should clarify the relationship between the rules which specifically protect the environment during armed conflict - both conventional and customary - and the general rules of ius in bello which protect civilian objects during armed conflict. 